\title{
The Customs Union in the CIS
}

Konstantin Borodin

Russian Institute of Agricultural Problems and Information Support, n.a. A.A. Nikonov (VIAPI), Moscow, Russia

Anton Strokov

Lomonosov Moscow State University, Moscow, Russia

\begin{abstract}
On the basis of data on trade among the Russian Federation, Belarus, and Kazakhstan, an attempt is made to assess the existing trends in trade before they formed the Customs Union within the Eurasian Economic Community and the very first results of the Customs Union activities. The removal of tariffs in mutual trade between Russia and Belarus, as our study shows, has not led to the development of mutual trade, although it helped Belarus to improve some of its macroeconomic indicators. Kazakhstan's accession to the Preferential Trade Agreement between Russia and Belarus stimulated the trade creation effect in some commodity groups (73 - articles of iron and steel). At the same time, in the overwhelming majority of trade sectors that showed a relatively high trade activity of the CU countries, a large share belongs to the EU countries; China also shows growing dynamics in trade with the CU countries. Using two options of the gravity model, we evaluated the Customs Union effects, which in their entirety confirmed that the Customs Union is dominated not by mutual trade but by trade with the countries from the rest of the world, including the Commonwealth of Independent States countries. Moreover, the extended option of the model, which takes into account the export of the
\end{abstract}

\footnotetext{
* Corresponding Author: Konstantin Borodin; Russian Institute of Agricultural Problems and Information Support, n.a. A.A. Nikonov (VIAPI), Bolshoy Kharitonyevsky pereulok, 21/6, bld. 1, 105064, post box 342, Moscow, Russia; Tel: +7 4956215523,E-mail: borkg_cd@mail.ru.

Co-Author: Anton Strokov; Eurasian Center for Food Security (ECFS) at Lomonosov Moscow State University, Leninskiye goru, 1, bld. 46, 119991 Moscow, Russia; Tel: +7 9154850918, E-mail: strokov@ecfs.msu.ru.
} 
basic product groups, has shown that the fuel group is the most important factor for the Customs Union countries in terms of export development. Mineral fuels belong to the product group 27 along with oils and distillation products.

\section{JEL Classifications: F15}

Keywords: Customs Union of Eurasian Economic Community, Trade, Gravity Model

\section{Introduction}

Regionalization is one of the most stable phenomena in the global economy. Advantages of regional integration include allowing producers to expand their tax-free sales and for customers to purchase goods at lower prices. The European Union was able to achieve the most advanced forms of integration. Other well-known and stable groupings are North American Free Trade Agreement (NAFTA) and Southern Common Market (MERCOSUR). However, a much greater number of regional Preferential Trade Agreements (PTAs) may in practice run into fairly serious problems in developing mutual trade, yielding no noticeable gains to the member countries.

If we view PTAs theoretically, then Viner (1950) was the first to point out that PTAs do not necessarily bring positive changes in welfare, depending on the effects of trade creation and trade diversion.

In recent years, the problem of regional integration in its pure form has exhausted itself to some extent (as a separate field of theoretical research), and a new scientific trend has emerged instead that studies the problems of dominance between multilateral agreements and the liberalization effects of PTAs. ${ }^{1}$

In the Customs Union of Eurasian Economic Community ${ }^{2}$ which is a regional association of three countries (Belarus, Kazakhstan, and Russia), owing to Russia's accession to the World Trade Organization (WTO) in August 2012, has ceased to be free from numerous commitments of this organization.

All issues of subordination between the provisions of international treaties signed

\footnotetext{
An overview of the main results is contained in the work by Krishna P. (2012).

${ }^{2}$ Hereafter referred to as CU or Customs Union of EurAsEC.
} 
within the CU and the WTO Agreements that regulate the establishment of customs unions were settled on May 19, 2011, when the CU member countries signed the Treaty on the Functioning of the CU within the Framework of the multilateral trade system, which noted that the WTO Agreements should prevail over respective provisions of the international treaties concluded within the framework of the Customs Union of EurAsEC.

The treaty envisages that, from the date of accession of any of the $\mathrm{CU}$ member countries to the WTO, the rates of the Common Customs Tariff of the Customs Union of EurAsEC shall not exceed the import tariff rates stipulated in the schedule of concessions and commitments on Goods, which is annexed to that party's protocol of accession to the WTO, unless otherwise provided for in the WTO Agreement.

The CU case indicates that two countries, Russia and Belarus, have canceled customs duties in trade between each other since 2001. True, some nontariff restrictions still remain. In fact, the declaration of establishing the CU among Belarus, Kazakhstan, and Russia means that Kazakhstan joins the regime of duty-free trade between Russia and Belarus and that the three countries introduce a uniform tariff. In addition, since the three countries were members of the EurAsEC before the CU establishment, certain preferences, not necessarily in tariff regulation, were envisaged, and they could also contribute to the distortion of the before the CU establishment picture.

Among the causes that might also affect the experimental integrity before and after $\mathrm{CU}$ is the financial crisis of the late 2000s, which to some extent led to a decrease in trade, and this decrease might differently affect trade between the $\mathrm{CU}$ countries and the rest of the world and between the CU member countries. In addition, several other changes in the world economy might also affect the before the CU phase. This is the rapid economic growth of new industrial countries, with which Russia and Kazakhstan have, primarily, close trade relations, and the expansion of the EU, whose role is still very substantial for $\mathrm{CU}$ countries.

Moreover, there may also be different levels of state support for domestic producers in the three countries. There are grounds to believe that mostly political motives underlay the CU establishment. This is evidenced by the fact that, since the early 1990s, trends in trade with the rest of the world, as well as in mutual trade, have been characterized by centrifugal rather than centripetal forces for the CU countries, which earlier had been engaged in all the main sub-regional blocs after the disintegration of the Soviet Union.

The motivation for trade creation with the subsequent problems that exist in the economies of these countries, such as the reduction of processing industries and the 
growth of raw-material industries, was, most probably, absent. There was a common desire to create conditions for the development of mutual trade, even by means of its diversion from more efficient producers in the rest of the world.

The situation with the establishment of the Customs Union of EurAsEC has some common traits with the establishment of NAFTA. First, in both cases, the PTA includes three countries; second, before the establishment of each of these two blocs, two countries were previously parties to a PTA (the United States and Canada to NAFTA; Russia and Belarus removed tariffs in mutual trade before the CU). Unlike NAFTA, much less attention was paid to the study of integration processes in the Commonwealth of Independent States (CIS) space. ${ }^{3}$

In particular, the work by Michalopoulos and Tarr (2004) was dedicated to the formation of trade blocs in the CIS. It assessed prospects for the establishment of a PTA (a free trade zone or a custom union as a form of integration) with the participation of Belarus, Kazakhstan, Russia, and the Kyrgyz Republic. The main conclusion was that dynamic and static effects related to it would rather be negative.

Lúcio de Souza's work (2011) contains opinions on the establishment of the Customs Union of EurAsEC, made with the help of the Global Trade Analysis Project (GTAP) model. According to these findings, the Customs Union of EurAsEC will reduce the countries' GDPs because trade diversion effects will prevail over trade creation effects.

This work is an attempt to evaluate trends that have emerged in trade between the $\mathrm{CU}$ partner countries before the CU establishment, as well as the first CU effects.

Section II gives a brief history of establishing trade blocs with Russia's participation on the territory of the former Soviet Union. Section III analyzes data on trade between the three countries, considers the main trends in trade over the previous period, and attempts to assess the first CU effects. Section IV attempts to identify product groups that have the potential for trade creation effects for the CU by analyzing the shares of Kazakhstan, the European Union, and China in Russia's imports, as well as import tariffs for these countries. In addition, this section attempts to identify the presence of trends for the development of mutual trade between the $\mathrm{CU}$ countries and the $\mathrm{CU}$ trade relations with other CIS countries and the EU countries on the basis of the gravity model. The geographical location of Customs Union of EurAsEC is shown on Figure 1.

\footnotetext{
${ }^{3}$ The influence of PTAs on NAFTA is assessed in a number of works, including Krueger (1999), which was used as a methodological manual for writing this article.
} 


\section{Figure 1. The Customs Union of EurAsEC (Russia, Kazakhstan, Belarus)}

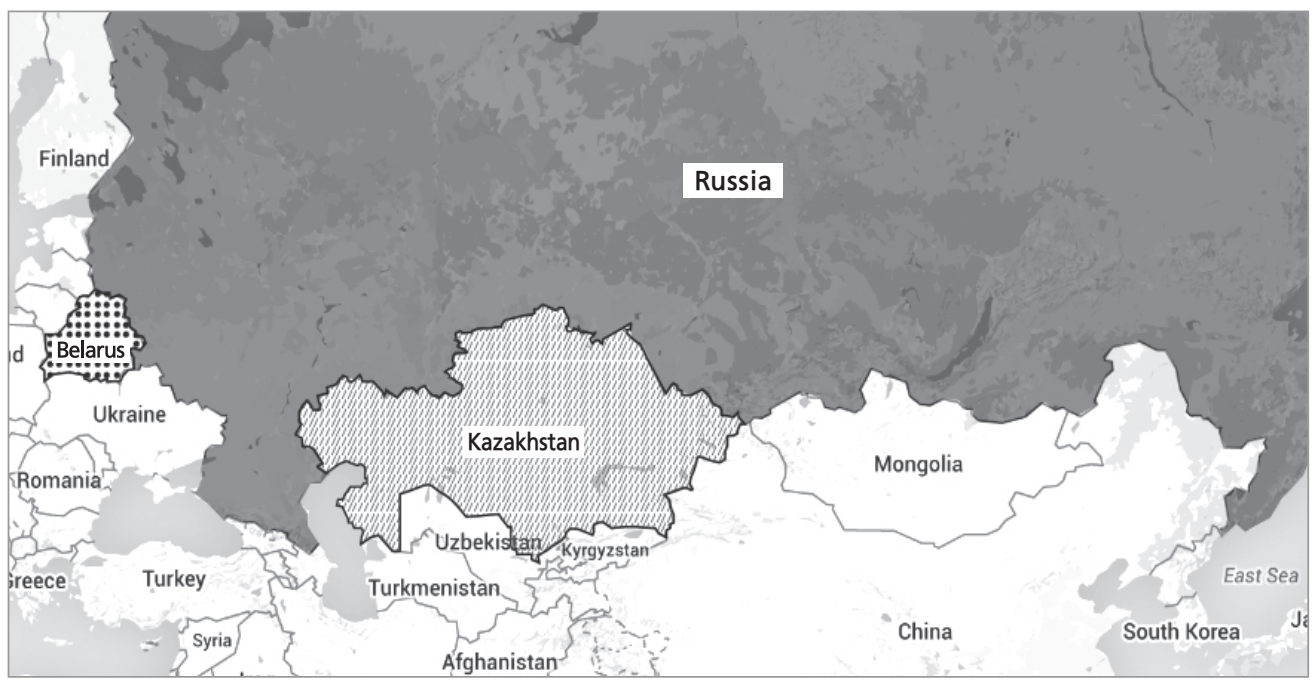

(Source) http://social.un.org/coopsyear/coops-youth-map.html.

\section{History of Regional Integration in the Post-Soviet Era}

Before the analysis of mutual trade between the CU countries, we should give a brief overview of how regional integration has developed in the ex- Union of Soviet Socialist Republics (USSR) era. This will allow us to show that all of the previous major attempts to create regional agreements have been associated one way or another with the current participants in the CU EurAsEC, as well as to consider briefly the reasonings behind the failures of the previous regional agreements.

After the disintegration of the Soviet Union in 1991, the Commonwealth of Independent States (CIS) was established on the basis of the Agreement, signed in Minsk by Russia, Belorussia, and Ukraine on December 8, 1991, and the Protocol to the Agreement of December 21, 1991, which Georgia joined later, in December 1993.

In 1993, the CIS countries signed the Agreement on the Establishment of an Economic Union for which the goal was for the stage-by-stage creation of a common market for goods, services, capital, and labor. Within the implementation of the declared long-term goal, the agreement was reached in the creation of a Free Trade Zone in 1994. 
However, this agreement has never been implemented in practice, to say nothing of the proposed Economic Union.

Problems that arose in multilateral agreements between the CIS countries made them switch to bilateral agreements. Small sub-regional groupings emerged as a result. The first step in this direction was the establishment in January 1995 of the Customs Union ${ }^{4}$, which included Belarus, Kazakhstan, and Russia and was later joined by Kyrgyzstan (March 1996) and Tajikistan (February 1999). A more advanced form of integration was in place between Russia and Belarus. They had abolished customs controls between them since 1995. However, Belarus's re-export of Russian oil in the late 1990s led to the introduction of some restrictions.

An attempt to infuse a new incentive for integration was the transformation of the Customs Union from the 1995 pattern consisting of a CU with five member countries into the Eurasian Economic Community (EurAsEC) in 2001. However, symptoms of the old disease once again became apparent - the inability to build multilateral relations, which resulted in barriers to mutual trade. Therefore, in August 2006, at the EurAsEC Interstate Council, a decision was again made to establish the Customs Union of three states - Belarus, Russia, and Kazakhstan, which set to work in January 2010.

Very little time has passed to make deliberate assessments of which direction the development of integration processes is taking in the $\mathrm{CU}$; to be more precise, we have data for one year, 2010, and, in this case, it would be proper to assess the main trends that have emerged in trade between the CU countries since the early 2000s and, if possible, to make safe estimates of the effects after the CU formation.

Despite the fact that the Agreement came into effect in January 2010, not all tariffs between Russia, Belarus, and Kazakhstan had been removed by that time. Moreover, Russia and Belarus had established tariff barriers in their mutual trade even before that, which might affect trade flows after the beginning of 2010. The three countries were not WTO members before the CU establishment, and WTO membership implies compliance with a number of requirements to liberalize the domestic market. At the same time, all three countries were and currently are members of the EurAsEC, an integrated association that envisages certain mutual preferences.

\footnotetext{
${ }^{4}$ Customs Union is the official name of this union which is shown in the official document of agreement between three countries, Russia, Belarus and Kazakhstan http://www.customsunion.ru/info/2529.html.
} 


\section{Mutual Trade between the CU EurAsEC Member Countries}

These conditions require that we try to specify the main trends in the trade of the CU countries over the 2002 2010 period, give a safe assessment of trade flows in order to eliminate the effect of other factors, and analyze trade between the CU partners before and after the $\mathrm{CU}$ formation.

The inflation rate in the three countries was very significant especially in the beginning of the period under consideration, i.e., 2002. In Belarus, it was very high, 42.5\%; in Russia, 15.8\%; and in Kazakhstan, 5.8\%, which was unusually low for the CIS countries. By 2010, these indicators decreased to 7.7\%, 6.9\%, and 7.1\%, respectively. For the purposes of subsequent simplification, all cost indicators in the trade of the three countries were converted to US dollars at an annual average rate.

Once again we note that the date of the formal start of integration is 2010, and the absence of a time interval long enough to assess this integration does not allow us to interpret unambiguously the data for that year as the result of an effective preferential agreement. At the same time, in some cases, we will attempt to pay special attention and make safe assessments of the results of 2008 2009 (before integration) and 2010 (after integration). Therefore, this section will largely deal with general assessments of the development of mutual trade between the CU countries. 
Table 1. Foreign trade of the current CU EurAsEC member countries

(Measurement unit: Billion US dollars)

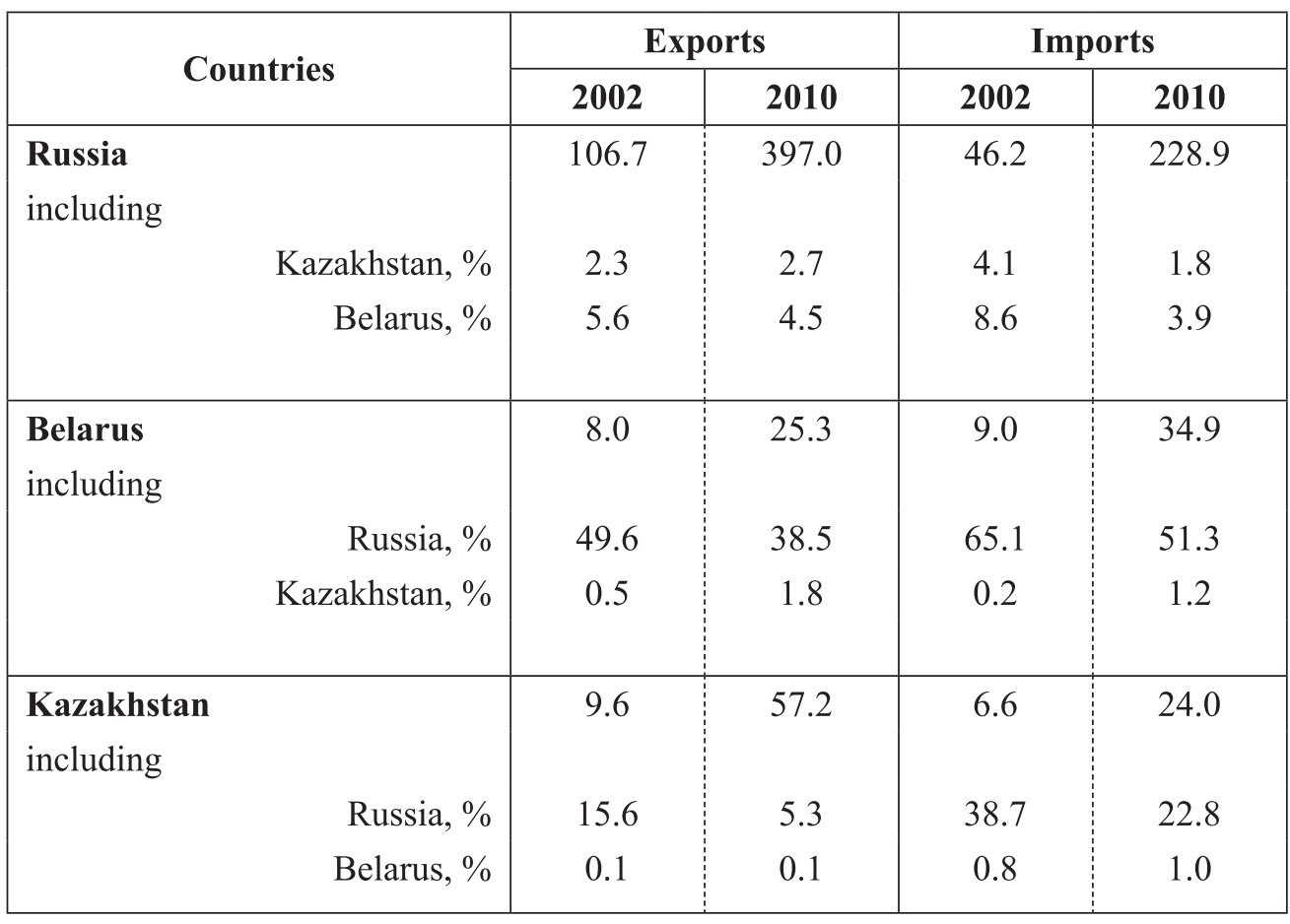

(Source) International Trade Center, The Government of Russia, Customs Union of EurAsEC.

Over the 2002 2010 period, the share of Russian exports to Kazakhstan increased by $20 \%$, and that to Belarus decreased by $18.7 \%$; although the initial shares of exports to these countries in 2002 were small, $2.3 \%$ and $5.6 \%$, respectively as shown in Table 1. At the same time, the shares of Kazakhstan and Belarus in Russian imports decreased by 2010 by 2.3 and 2.2 times, respectively, reaching 1.8\% for Kazakhstan and $3.9 \%$ for Belarus in 2010.

The shares of Belarus and Kazakhstan in mutual trade are insignificant; the significance of Kazakhstan as Belarus's trade partner is higher, and this is reflected in the dynamics of Kazakhstan's shares in Belarus's foreign trade.

Russia's share in Belarus's exports in 2002 was 49.6\%; in Belarus's imports in the same year, it was also very high, 65.1\%; however, in the following years, both shares decreased by more than $20 \%$, reaching, respectively, $38.5 \%$ in exports and $51.3 \%$ in imports in 2010. At the same time, we should note that Russia's share in Belarus's exports increased from $31.5 \%$ in 2009 to $38.5 \%$ in 2010 . However, if we compare 
Russia's share in Kazakhstan's exports and imports over the same two years, we will see the opposite picture. Russia's share in Kazakhstan's exports decreased from 8.2\% to 5.3\% (or 1.6 times), and this drop was most significant starting from 2005. Russia's share in Kazakhstan's imports during 2009 2010 decreased from $31.3 \%$ to $22.8 \%$ (or 1.4 times), and this drop was most noticeable compared to other years.

Thus, Russia's share in the foreign trade of other CU member countries is decreasing. Meanwhile, Russia's share in Kazakhstan's exports and especially imports is still very noticeable. Once again, we make the reservation that the above assessments are difficult to justify exclusively by integration effects. Nevertheless, these results indicate the presence of certain centrifugal dynamics.

After we have evaluated the aggregated trade flows in general, at the next stage, it seems expedient to disaggregate these data and to study the behavior of exports and imports within product categories, the volumes of which in the mutual trade of the CU countries were relatively high or the $\mathrm{CU}$ countries share of which in mutual trade was significant in the period under study.

Thus, for mutual exports between Customs Union of EurAsEC countries, we selected the following product groups: mineral fuels, oils, distillation products (27); machinery, nuclear reactors, boilers (84); vehicles other than railway, tramway (87); dairy products, eggs, honey, edible animal products (04); iron and steel (72); articles of iron and steel (73); aluminum and articles thereof (76); ores, slag and ash (26); fertilizers (31); meat and edible meat offal (02).

Similarly, the biggest import product groups were also selected: electrical, electronic equipment (85); machinery, nuclear reactors, boilers (84); vehicles other than railway, tramway (87); meat and edible meat offal (02); iron and steel (72); articles of iron and steel (73); plastics and articles thereof (39); optical, photo, technical, medical apparatus (90); pharmaceutical products (30); mineral fuels, oils, distillation products (27).

The essential feature of total exports from the CU countries is that the biggest share belongs to group 27 (mineral fuels, oils, and distillation products): in the 2002 2010 period it increased from $54.7 \%$ to $68 \%$ in Russia's exports, from $20.3 \%$ to $28.1 \%$ in Belarus's exports, and from $58.3 \%$ to $71.7 \%$ in Kazakhstan's exports. In Russia's exports only to the CU countries, its share increased from $4.7 \%$ in 2002 to $6.7 \%$ in 2009 and declined to $4.4 \%$ in 2010. In Kazakhstan's exports, its share declined from $12.8 \%$ to $2.1 \%$.

The next group that holds a big share in total exports is iron and steel (72). Russia's share to the CU countries rose from $7.4 \%$ to $8.7 \%$, the share of Kazakhstan's exports 
decreased from $13.1 \%$ to $10.3 \%$ and Belarus from $26.6 \%$ to $24.1 \%$. A large share of exports belongs to machinery, nuclear reactors, boilers (84); vehicles other than railway, tramway (87); dairy products, eggs, honey, edible animal products (04). The share of Russia in all 3 groups declined, but the greatest decline was in Kazakhstan, especially in group 87. Except for the 04 group, Belarus's exports share decreased. The share of the articles of steel (73) exports to the CU countries has grown in Russia and Kazakhstan from $35.7 \%$ to $39.5 \%$ and from $17.8 \%$ to $45.8 \%$, respectively. Belarus's share dropped from $67 \%$ to $60.8 \%$. Meat exports from Belarus are mostly supplied to its CU partners.

In the CU countries' total imports, the industrial/machinery groups $(84,85,87)$ take the most significant part but the share of the CU partners in all of the 3 groups is decreasing. Among other big groups, the share of Russia's imports to the CU countries also declined except for meat, its share increased from $3.2 \%$ to $10.2 \%$. The share of Kazakhstan in imports from the CU countries declined in all groups except for meat and mineral fuels. Belarus's share decreased in all groups.

Our findings show that Russia still holds a leading position in trade between the CU countries as the major CU link. Meanwhile, the CU countries' shares in mutual trade have essentially shown a downward trend.

The analysis of the product groups has shown that the relatively stable trade shares of the CU countries comprise fuel and raw-material products (groups 27, 72, 73, 76, 26) and agricultural products (groups 2, 4). Industrial/machinery products from third countries increasingly oust the CU products. As a result, the CU countries increasingly trade fuel and raw-material products and agricultural products, which is the effect of the growing specialization of Russia and Kazakhstan in fuel and raw-material products and Belarus in agricultural products.

\section{Will Centrifugal Dynamics Continue?}

Preliminary analysis of trade data has shown that, despite the growth of the cost indicators of trade in absolute values, the relative values show a de-escalation of mutual trade between the $\mathrm{CU}$ member countries. Consequently, the preliminary trade results indicate that the $\mathrm{CU}$ establishment and the introduction of a uniform tariff have practically not affected the trends that existed before the CU establishment. A possible 
answer here is that we have only considered one year (2010), when the three countries were within the CU. It is quite possible that it will take several years to break the previous trend. At the same time, the PTA and the related mutual abolishment of duties between Russia and Belarus in 2001 were unable to overcome the trend of preemptive growth of trade with the rest of the world.

In this work, we study trade between CU partner countries beginning from 2002. It appears difficult to see the effects of trade creation and trade diversion in trade between Russia and Belarus since this would require us to analyze data for the period before 2001, that is, when tariffs were used in trade between these countries. Nevertheless, a brief conclusion about the relative trade dynamics between Russia and Belarus from 2002 to 2010 should be made once again. We have previously shown that both Belarus's share in Russian imports and exports as well as Russia's share in Belarus's imports and exports was decreasing. In other words, de-escalation characterizes mutual trade between Russia and Belarus in the conditions of preferences if we judge by specific values.

\section{A. Trade creation in the Customs Union}

Kazakhstan's trade data may be used for preliminary analysis with a view to trade creation and trade diversion. To this end, we intended to investigate changes in Kazakhstan's shares in Russian imports in the sectors singled out previously, where trade between the CU countries was most intensive. Then, our analysis will involve similar data for the European Union (EU), Russia's major trade partner, as well as for China, which is dynamically building up its presence in the Russian market. Thus, this will be an attempt to assess the degree by which the CU trade increased owing to the trade shares of the countries from the rest of the world.

The share of Kazakhstan as Russia's trade partner is rather small, 2 3\% in exports and $2 \sim 4 \%$ in imports. It is lower than that of China or the EU. Table 2 presents the shares of Kazakhstan, the EU, and China in Russia's imports for 2008 and 2010 in those groups where trade was most intensive. The import tariffs for these groups are also shown.

Considering the fact that trade data in the CU countries is available only for 2010, the tariff scale is given as an additional source of analysis and it is hard to argue whether it affected trade or not in such a short time.

Officially, the 2008 import tariffs for Kazakhstan, the EU, and China were identical by product group. But Kazakhstan as Russia's long-time partner in such unions like 
EurAsEC had some preferential agreements that could have affected the decline of tariffs between Kazakhstan and Russia. It can be seen that in some cases the average tariff for two-digit level product groups has risen. The reason is the increase of tariffs in four-digit product groups. For example, among the meat and meat products (02), the tariffs rose for raw products (chilled meat), but in the iron and steel groups (72 and 73), the tariffs rose mostly for first-stage processing products. In other cases the tariffs lowered.

As a CU member, Kazakhstan has moved into a more beneficial position, but its share in Russia's imports rose only in the articles of iron and steel (73). Both China's and the EU's share in this group increased despite the growth of tariffs from $13.69 \%$ to $14.07 \%$.

Table 2. Import tariffs and shares of countries in Russia's imports

(Measurement Unit: \%)

\begin{tabular}{|c|c|c|c|c|c|c|c|c|c|c|}
\hline \multirow{3}{*}{ Code } & \multicolumn{4}{|c|}{ Import tariffs of Russia } & \multicolumn{3}{c|}{ The shares of countries in Russia's imports } \\
\cline { 2 - 11 } & Kazakhstan & \multicolumn{2}{|c|}{ EU and China } & \multicolumn{2}{|c|}{ Kazakhstan } & \multicolumn{2}{|c|}{ EU } & \multicolumn{2}{c|}{ China } \\
\cline { 2 - 11 } & $\mathbf{2 0 0 8}$ & $\mathbf{2 0 1 0}$ & $\mathbf{2 0 0 8}$ & $\mathbf{2 0 1 0}$ & $\mathbf{2 0 0 8}$ & $\mathbf{2 0 1 0}$ & $\mathbf{2 0 0 8}$ & $\mathbf{2 0 1 0}$ & $\mathbf{2 0 0 8}$ & $\mathbf{2 0 1 0}$ \\
\hline 30 & 9.05 & 0 & 9.05 & 7.39 & 0.0 & 0.0 & 76.5 & 74.3 & 0.4 & 0.6 \\
\hline 2 & 20.92 & 0 & 20.92 & 27.75 & 0.0 & 0.0 & 24.7 & 32.9 & 0.1 & 0.1 \\
\hline 39 & 11.48 & 0 & 11.48 & 10.37 & 0.2 & 0.1 & 55.5 & 55.5 & 15.5 & 16 \\
\hline 72 & 4.79 & 0 & 4.79 & 5.20 & 13.7 & 7.2 & 21.2 & 24.6 & 11.6 & 15.8 \\
\hline 73 & 13.69 & 0 & 13.69 & 14.07 & 0.4 & 0.8 & 42.8 & 43.7 & 20 & 21.2 \\
\hline 84 & 3.75 & 0 & 3.75 & 2.97 & 0.4 & 0.1 & 56.4 & 49 & 17.5 & 24.1 \\
\hline 85 & 8.11 & 0 & 8.11 & 6.69 & 0.3 & 0.1 & 41.9 & 36.6 & 28.4 & 33.4 \\
\hline 87 & 11.49 & 0 & 11.49 & 11.18 & 0.0 & 0.0 & 44.9 & 47.8 & 3.7 & 4.5 \\
\hline 90 & 5.76 & 0 & 5.76 & 5.13 & 0.0 & 0.0 & 45.6 & 51.2 & 10.3 & 11.7 \\
\hline
\end{tabular}

(Source) International Trade Center, The Government of Russia, Customs Union of EurAsEC, www.wto-inform.ru.

It is easy to notice that the EU share prevails in almost all product groups that are intensively traded within the CU. In industrial/machinery groups (84 and 85), the EU share in Russia's imports is decreasing and China's share is growing. In 2002 2010, the correlation between China's and the EU shares was negative, -0.759. Taking into account the growth of Kazakhstan's exports to Russia in group 73, the building block conditions may be built in this sector. 
The first simple conclusion is that trade has increased between the $\mathrm{CU}$ and the rest of the world, but declined among the CU countries. Adapting it as a consequence of the Kemp-Wan theorem (1976), it would mean that initially the CU did not decrease the world welfare, but could have brought some benefits for the CU countries. However, taking into account of only one year effect of the $\mathrm{CU}$, our conclusions cannot be so adamant.

\section{B. Gravity equations}

Gravity models are still widely used in theory and practice for PTA assessment. A sufficiently large number of works are dedicated to the study of regional integration problems with the use of gravity models. ${ }^{5}$

To assess changes in trade, we built a regression equation in which the export logarithm was a variable dependent on distances, GDP, GDP per capita, and several other variables. Dummy variables were added when both countries were parties to the Customs Union of EurAsEC or when the importing country was a party to another PTA like CIS or EU. zIn addition, to estimate the significance of trade of a certain product group for the $\mathrm{CU}$ countries, corresponding dummy variables were added: agricultural and food products (1-24); salt, sulfur, earth, stone, plaster, lime cement, ores, slag and ash $(25,26)$; mineral fuels, oils, and distillation products $(27)$; chemistry products $(28-40)$; metals (72-83); and industrial/machinery products (84-90).

The data includes the value of exports, distance, GDP, GDP per capita, common language (Russian), the exchange rate ratio of an exporting country to an importing country for 2002, 2004, 2006, 2008, and 2010.

The regression equation takes this form:

$\operatorname{Exports}(I, J)=C+a 11(Y 04)+a 12(Y 06)+a 13(Y 08)+a 14(Y 10)+b 1(G D P(I))$

$+b 2(G D P(J))+c 1(G D P P C(I))+c 2(G D P P C(J))+e 1(D I S T(I, J))+e 2(C O N T I G(I, J))$

$+f(S L(I, J))+\operatorname{dum} 1(C U(I, J))+\operatorname{dum} 2(C I S(J))+\operatorname{dum} 3(E U(J))+\operatorname{dum} 4(B E L(J))$

$+\operatorname{dum} 5(K A Z(J))+\operatorname{dum} 6(R U S(J))+\operatorname{dum} 7(A G R I)+\operatorname{dum} 8(O I L)$

$+\operatorname{dum} 9($ MACHIN $)+\operatorname{dum} 10($ MINER $)+\operatorname{dum} 11($ CHEM $)$

$+\operatorname{dum} 12(\operatorname{METAL})+g 1(\operatorname{EXCHAN}(I, J))+g 2(\operatorname{DIFWEL}(I, J))$

\footnotetext{
5 Greenaway D. and Milner C. (2002) generalized the main works on the use of gravity models to assess regional trade agreements. The importance of gravity equations for the analysis of trade blocs and trade is also given much attention in the collection edited by Frankel (1998).
} 
where $I$ and $J$ are the exporting and importing countries;

Exports $(I, J)$ are exports from country $I$ to country $J$;

$C$ is a constant;

$Y 04, Y 06, Y 08, Y 10$ are dummy variables of years (without the year 2002);

$G D P$ is a GDP in USD in the prices of 2010;

$G P P C$ is a GDP per capita;

$\operatorname{DIST}(I, J)$ is the distance between the capitals of $I$ and $J$;

CONTIG $(I, J)$ is a dummy variable, which equals 1 if the trading partners have a border;

$S L(I, J)$ equals 1 if the countries have Russian language;

$C U(I, J)$ equals 1 if $I$ and $J$ are CU members;

$C I S(J)$ equals 1 if the importer is a CIS member;

$E U(J)$ equals 1 if the importer is an EU member;

$B E L(J), K A Z(J)$, and RUS $(J)$ equal 1 if the importer is Belarus, Kazakhstan, and Russia, respectively;

AGRI, OIL, MACHIN, MINER, CHEM, METAL equal 1 if the product is, respectively, agricultural and food products (1-24); mineral fuels, oils, and distillation products (27); machinery-industry products (89-90); salt, sulfur, earth, stone, plaster, lime cement, ores, slag and ash $(25,26)$; chemistry products $(28-40)$; and metals $(72-83)$.

$\operatorname{EXCHAN}(I, J)$ is the exchange rate ratio between $I$ and $J$.

The variable DIFWEL was included to investigate the difference between the exporter's and importer's welfare:

$$
D I F W E L=1+\frac{C A P_{-} E X P-C A P_{-} I M P}{C A P_{-} E X P+C A P_{-} I M P}
$$

where $C A P \_E X P$ is exporter's GDP per capita,

CAP_IMP is importer's GDP per capita.

In this case, the welfare is assumed to be the per capita income. Logically, the higher the exporter's GDP per capita indicator than the similar importer's indicator, the sooner DIFWEL $\rightarrow 2$. If, vice versa, the given importer's indicator is much higher than the exporter's indicator, then $D I F W E L \rightarrow 0$. If both indicators are roughly equal, then $D I F W E L \rightarrow 1$. Theoretically, a situation is possible in which, for pairs close in value, this indicator may stay practically unchanged $(D I F W E L \approx 1)$ for both large and small absolute values. At the same time, if observations are few and taking into account the fact that 
cases when these two indicators are the same are rare in practice, the influence of such cases will, most probably, be smoothed. The indicator's form (the figure of one before the decimal) was chosen with respect to its further logarithmation. After the regression equation was drawn, the initial data were prepared in two ways.

\section{Extended version}

For the extended version of the model, we used 29,917 observations ${ }^{6}$ - the exports of two-digit groups to different countries from the customs statistics ${ }^{7}$ of Belarus, Kazakhstan, and Russia for 2002, 2004, 2006, 2008, and 2010. All variables were converted to US dollars and then to constant 2010 dollars.

The regression of consolidated time series (taken in their cross-sections) was then estimated. Table 3 shows the result of estimating Equation (1). We can see that the coefficients of GDP, GDP per capita, and distance are very significant, thus confirming for the CU countries the idea on which the gravity equations are based. The presence of the negative sign in the distance variable implies that the shorter the distance, the larger the export volumes to the neighboring countries. Exports were not reduced in any of the years under study, even in 2008 and 2010, despite the global financial crisis, which is evidenced by the positive sign of the coefficient of elasticity before dummy variables Y2008 and Y2010. The presence of a common border and a common language (dummy variables CONTIG, SL) contributed to export growth.

Let us consider coefficients related to dummy variables for PTA relations, which should clarify the answer to the questions "Did trade relations develop between the CU countries?" "Did trade expand between the CU countries and the CIS countries?" and "Did mutual trade grow between the CU and EU countries?"

The coefficient before the CU dummy variable implies that mutual trade between the CU countries did not increase. Here, it is once again important to note that we are talking about the data covering all the years under consideration. Even if hypothetical trade growth could have occurred in the last year 2010, the previous opposite CU trend could have fully leveled this short-term event.

The answer to the second question is much more optimistic. Indeed, trade did expand between the CU countries and the CIS countries. It may appear paradoxical, but the preemptive development of the $\mathrm{CU}$ countries trade relations covered not the

\footnotetext{
${ }^{6} 350$ observations were removed because they were equal to zero.

So-called two-digit level 01-99 of the foreign trade nomenclature of goods.
} 
CU members but other CIS countries. Trade interaction of the CU with countries of the European Union is insignificant, but exports to these countries, as distinct from the CU countries, are growing.

The importance of the CU countries as consumers of products manufactured by the $\mathrm{CU}$ is of certain interest. From this perspective, the most serious importer is Kazakhstan, which is confirmed by the $t$-statistics, while Russia's contribution to integration is less noticeable, and Belarus is largely building its participation in the $\mathrm{CU}$ as an exporter.

In this expanded variant of the model, we used dummy variables, and their equivalence to 1 meant that goods belonged to a certain product group. Thus, we were able to identify the importance of certain product groups for the CU countries exports. The most important export group for the CU countries is the mineral fuels, oils and distillation products (27). Also, high export values belong to the industrial/machinery products (84-90), metals (72-83), and chemistry products (28-40). The share of the agricultural and food products (1-24) is rather low.

Currency rate ratios are statistically meaningful and show that the higher the currency rate in the exporting country relative to the importing country, the more successful the development of export is. 
Table 3. Results of the extended gravity model

\begin{tabular}{|c|c|c|c|c|}
\hline Independent variables & Abbreviation & B & t-statistics & Significance \\
\hline Constant & $C$ & 12.190 & 7.509 & 0.000 \\
\hline Distance & $D I S T(I . J)$ & -0.966 & -29.520 & 0.000 \\
\hline Exporter's GDP & $G D P(I)$ & 0.981 & 20.715 & 0.000 \\
\hline Importer's GDP & $G D P(J)$ & 0.405 & 20.524 & 0.000 \\
\hline Exporter's GDP per capita & $G D P P C(I)$ & -1.864 & -6.653 & 0.000 \\
\hline Importer's GDP per capita & $G D P P C(J)$ & -0.304 & -15.469 & 0.000 \\
\hline 2004 & $Y 04^{*}$ & 0.626 & 4.902 & 0.000 \\
\hline 2006 & $Y 06^{*}$ & 1.284 & 5.509 & 0.000 \\
\hline 2008 & $Y 08^{*}$ & 1.819 & 5.382 & 0.000 \\
\hline 2010 & $Y 10^{*}$ & 1.823 & 5.817 & 0.000 \\
\hline Border & $\operatorname{CONTIG}(I . J)^{*}$ & 0.393 & 7.098 & 0.000 \\
\hline $\begin{array}{l}\text { If both trading partners have } \\
\text { Russian language }\end{array}$ & $S L(I . J) *$ & 0.361 & 3.961 & 0.001 \\
\hline $\begin{array}{l}\text { If both trading partners are } \\
\text { members of the Customs Union } \\
\text { of EurAsEC }\end{array}$ & $C U(I . J) *$ & -0.444 & -2.574 & 0.010 \\
\hline If importer is a CIS member & $C I S(J)^{*}$ & 1.022 & 12.560 & 0.000 \\
\hline If importer is an EU member & $E U(J)^{*}$ & 0.082 & 1.624 & 0.104 \\
\hline If importer is Belarus & $B E L(J)^{*}$ & 0.284 & 1.077 & 0.282 \\
\hline If importer is Kazakhstan & $K A Z(J)^{*}$ & 1.343 & 10.129 & 0.000 \\
\hline
\end{tabular}

(Note) Dummy variables.

(Source) Authors' estimations based on the data of International Trade Center and World Bank. 
Table 3. Results of the extended gravity model

(continued)

\begin{tabular}{|l|c|c|c|c|}
\hline \multicolumn{1}{|c|}{ Independent variables } & Abbreviation & B & t-statistics & Significance \\
\hline If importer is Russia & RUS $(J)^{*}$ & 0.751 & 5.703 & 0.000 \\
\hline $\begin{array}{l}\text { If the good is included in product } \\
\text { groups 1-24 (agriculture and food } \\
\text { products) }\end{array}$ & AGRI* & 0.414 & 8.701 & 0.000 \\
\hline $\begin{array}{l}\text { If the good is included in product } \\
\text { group 27 (mineral fuels, oils and } \\
\text { distillation products) }\end{array}$ & OIL* & 6.621 & 56.297 & 0.000 \\
\hline $\begin{array}{l}\text { If the good is included in product } \\
\text { groups } 84-90 \text { (machinery industry } \\
\text { products) }\end{array}$ & MACHIN* & 2.205 & 40.383 & 0.000 \\
\hline $\begin{array}{l}\text { If the good is included in product } \\
\text { groups 25 and 26 (salt, sulfur, } \\
\text { earth, stone, plaster, lime cement, } \\
\text { ores, slag and ash) }\end{array}$ & MINER* & 1.908 & 16.782 & 0.000 \\
\hline $\begin{array}{l}\text { If the good is included in product } \\
\text { groups 28-40 (chemistry products) }\end{array}$ & CHEM* & 1.435 & 29.565 & 0.000 \\
\hline $\begin{array}{l}\text { If the good is included in product } \\
\text { groups 72-83 (metals) }\end{array}$ & METAL* & 1.920 & 36.688 & 0.000 \\
\hline $\begin{array}{l}\text { The ratio of exporter's exchange } \\
\text { rate to importers }\end{array}$ & EXCHAN(I.J) & 0.023 & 2.455 & 0.014 \\
\hline $\begin{array}{l}\text { The difference between exporter's } \\
\text { and importer's welfare }\end{array}$ & DIFWEL $(I . J)$ & -0.113 & -2.735 & 0.000 \\
\hline$-1 .-13$ & & & \\
\hline
\end{tabular}

(Note) Dummy variables.

(Source) Authors' estimations based on the data of International Trade Center and World Bank.

Similar statistical significance characterizes the indicator of difference in the welfare levels of importing and exporting countries, DIFWELF, but with the negative sign; in other words, as this indicator grows, exports decrease insignificantly.

On the basis of the results estimated for the expanded model, the coefficient of correlation $\mathrm{R}$ was 0.514 , and coefficient of determination $\mathrm{R}^{2}$ was 0.264 . The coefficient of correlation is statistically meaningful, since the $f$-statistic is 428.9. The low coefficient 
of determination shows that we were unable to identify factors that were specific for different industries and that affected exports from Belarus, Kazakhstan, and Russia to different countries of the world. The DW coefficient is 0.848 , which indicates a significant positive residual autocorrelation.

In addition to the above independent variables, we tried to include the REMOTE variable, or the weighted (by GDP) mean distance from a country's trade partners ${ }^{8}$, into the model, but it turned out to be statistically insignificant and impaired the t-statistics of other variables.

\section{Aggregated variant}

As distinct from the first variant, in each observation of which the export of the corresponding product was indicated (for each two-digit group from 01 through 99) from one country to another, in the second variant, total exports were given in each observation (for all product classification codes) from a given exporting country to a given importing country.

For the aggregated variant of the model, we used 1,991 observations ${ }^{9}$, each of which reflected total exports from Belarus, Kazakhstan, and Russia to different countries of the world in 2002, 2004, 2006, 2008, and 2010. The export and GDP indicators here were also converted into constant 2010 dollars. The regression equation has fewer independent variables, because product groups were not itemized in this variant. In addition, we did not consider variables Y04, Y06, BEL, KAZ, and RUS, because of the low significance of their $t$-statistics.

Regression for the aggregated variant:

$\operatorname{Exports}(I, J)=C+a 11(Y 08)+a 12(Y 10)+b 1(G D P(I))$

$+b 2(G D P(J))+c 1(G D P P C(I))+c 2(G D P P C(J))+e 1(D I S T(I, J))+e 2(C O N T I G(I, J))$

$+f(S L(I, J))+\operatorname{dum} 1(C U(I, J))+\operatorname{dum} 2(C I S(J))+\operatorname{dum} 3(E U(J))$

$+g 1(\operatorname{EXCHAN}(I, J))+g 2(\operatorname{DIFWEL}(I, J))$

Table 4 shows the results of estimating Equation (3). Here, as well as in the expanded variant, the coefficients of GDP, GDP per capita, and distance are very significant.

\footnotetext{
${ }^{8}$ Estimated similarly to Krueger (1999).

${ }^{9} 59$ observations were removed because they were equal to zero.
} 
The negative sign before the variable of distance characterizes the inverse dependence between distance and export volumes. The dummy year variables show poor significance, and, consequently, they are not essential. In other words, no significant events that could affect exports took place during these years. The world financial crisis and the $\mathrm{CU}$ establishment may be classified as such events.

Compared to the expanded variant, the presence of a common border is still a significant indicator, and the presence of the Russian language becomes insignificant.

Coefficients related to the dummy variables for PTA relations should answer the same questions that were posed for the expanded variant concerning the development of trade relations between the $\mathrm{CU}$ countries, between the $\mathrm{CU}$ countries and the rest of the CIS, and between the CU countries and the EU countries. Here, the answers to the three questions are similar to those obtained for the expanded variant, except that an importer from the EU countries is a significant factor here. 
Table 4. Results of the aggregated gravity model

\begin{tabular}{|l|c|c|c|c|}
\hline \multicolumn{1}{|c|}{ Independent variables } & Abbreviation & B & t-statistics & Significance \\
\hline Constant & $C$ & 8.195 & 5.879 & 0.000 \\
\hline Distance & $D I S T(I . J)$ & -1.542 & -18.390 & 0.000 \\
\hline Exporter's GDP & $G D P(I)$ & 1.270 & 22.640 & 0.000 \\
\hline Importer's GDP & $G D P(J)$ & 1.029 & 34.531 & 0.000 \\
\hline Exporter's GDP per capita & $G D P P C(I)$ & -1.829 & -8.446 & 0.000 \\
\hline Importer's GDP per capita & $G D P P C(J)$ & 0.384 & 4.010 & 0.000 \\
\hline 2008 & $Y 08^{*}$ & 0.314 & 1.617 & 0.106 \\
\hline 2010 & $Y 10^{*}$ & 0.075 & 0.410 & 0.681 \\
\hline Border & $C O N T I G(I . J)^{*}$ & 0.661 & 2.615 & 0.009 \\
\hline $\begin{array}{l}\text { If both trading partners have } \\
\text { Russian language }\end{array}$ & $S L(I . J)^{*}$ & -0.145 & -0.378 & 0.705 \\
\hline $\begin{array}{l}\text { If both trading partners are } \\
\text { members of Customs Union } \\
\text { of EurAsEC }\end{array}$ & $C U(I . J)^{*}$ & -0.593 & -0.620 & 0.536 \\
\hline \begin{tabular}{l} 
If importer is a CIS member \\
\hline If importer is an EU member
\end{tabular} & CIS $(J)^{*}$ & 2.663 & 10.892 & 0.000 \\
\hline $\begin{array}{l}\text { The ratio of exporter's exchange } \\
\text { rate to importer's }\end{array}$ & EXCHAN $(I . J)$ & 0.049 & 2.331 & 0.020 \\
\hline $\begin{array}{l}\text { The difference between exporter's } \\
\text { and importer's welfare }\end{array}$ & $D I F W E L(I . J)$ & 1.365 & 7.406 & 0.000 \\
\hline
\end{tabular}

(Note) Dummy variables.

(Source) Authors' estimations based on the data of International Trade Center, World Bank.

Compared to the expanded variant, the DIFWELF indicator changed the sign and became significant. ${ }^{10}$

\footnotetext{
${ }^{10}$ For this variant of the model, we also tested a similar indicator, $\operatorname{ENDOW}(I, J)=|\ln G D P P C(I)-\ln G D P P C(J)|$, used, in particular, in De Benedictis et al. (2005), which turned out to be statistically insignificant in our model.
} 
According to the results calculated for the expanded model, the coefficient of correlation $\mathrm{R}=0.805$ and the coefficient of determination $\mathrm{R}^{2}=0.649$. The coefficient of correlation is statistically significant, because the $f$-statistic is 260.7 . The coefficient of determination confirms that we were able to identify $64.9 \%$ of factors that affect exports from Belarus, Kazakhstan, and Russia to different countries of the world. The DW coefficient is 1.44 , and this indicates a small positive residual autocorrelation.

For the aggregated version, we also checked the significance of dummy variables BEL, KAZ, and RUS; in other words, we evaluated whether Belarus, Kazakhstan, or Russia were importers, but their significance was low, and the variables of Belarus and Russia were also negative. For this reason, these variables were removed from the final version of the regression equation.

\section{Conclusion}

Despite attempts to create efficient regional Preferential Trade Agreements (PTAs) in the post-Soviet era, the trade of PTA countries, including the Customs Union (CU) of EurAsEC, is still developing primarily with the countries from the rest of the world.

The removal of tariffs in mutual trade between Russia and Belarus, as our study shows, has not led to the development of mutual trade, although it has helped Belarus to improve some of its macroeconomic indicators. Kazakhstan's accession to the PTA between Russia and Belarus may, probably, stimulate the trade creation effect in some product groups (73). At the same time, in the overwhelming majority of trade sectors that showed a relatively high trade activity within CU countries, a large share belongs to the European Union (EU) countries. China also shows growing dynamics in trade with the CU countries while there may be other countries that were not considered with whom trade relations may be more important for the CU countries than mutual trade.

An interesting fact is that CU trade grew with Commonwealth of Independent States (CIS) countries that were not CU members. This may lead to the conclusion that CU countries should probably look for more efficient trade partners among other CIS countries.

Let us consider the main factors that de-escalate trade between $\mathrm{CU}$ countries.

(i) A key factor that contributes to reduction in mutual trade between $\mathrm{CU}$ countries 
is the growing specialization of Russia and Kazakhstan in fuel and raw-material products and, as a consequence, the growing export shares of these product groups with simultaneous reduction in the shares of finished products.

Despite the fact that the modeling results confirm the significance of industrial/ machinery products for the $\mathrm{CU}$ countries exports, these exports are mainly supported by old cooperation ties between the three countries where at that time, the CU countries were within a single state, the Soviet Union; in addition, these export shares in mutual trade are decreasing.

The growing trade liberalization and relatively high inflation rates make CU countries' finished products non-competitive with consumer imports and other finished products from third countries. Accordingly, third countries satisfy CU countries' fairly high internal demand for a wide range of manufactured goods. Thus, CU countries import high-quality consumer goods from the EU countries and cheaper finished products mainly from China.

(ii) The development of trade within the $\mathrm{CU}$ is hindered to a certain extent by fairly long distances between Belarus and Kazakhstan where the distance between the capital cities is $3449 \mathrm{~km}$. The model results also confirm the substantial effect of distances between countries on trade. The territorial closeness of Belarus to European countries and that of Kazakhstan to Asian countries affects the development of trade relations between Belarus and the EU countries, particularly Poland, as well as between Kazakhstan and China.

Note also that the CU countries desire to accelerate integration processes, reflected in attempts to declare a breakthrough to higher integration steps (a customs union) instead of consistent and deliberate step-by-step progress. Probably, the transfer to higher integration steps should be well prepared; so that work in the CU environment does not require the solution of many unsettled issues. In particular, among such problems within the Customs Union of EurAsEC is customs clearance of automobiles and energy sources.

We would like to refer in detail to how Russia's membership in the World Trade Organization (WTO) may tell on the specific functioning of the CU and what consequences it infers for trade between the CU and EU countries. First, Russia will try to reduce the level of government support to agriculture and, probably, subsidies to industries in Belarus in order to level the competitive conditions in the CU. Second, Russia will be interested in the conditions of accession of Kazakhstan and Belarus to the WTO not being more liberal, although the terms of accession of each of these countries 
will most probably be agreed preliminarily between the CU countries.

The high provision with natural resources of the CU countries, primarily Russia, may favor the preemptive development of raw material exports to third countries under the conditions of liberalization, primarily, to the countries of the European Union. This, in particular, follows from the fact that, under Russia's commitments to the WTO, which were reached during negotiations with the EU, export duties on many raw materials will be completely removed within transitional periods of $1 \sim 5$ years.

Thus, the WTO factor may push Russia to further its fuel and raw material specialization. In addition, a reduced level of protection of Russia's domestic market will probably lead to a reduction in the supplies of industrial goods from Belarus and, as a consequence, will cause a decrease in trade in industrial goods within the CU.

Generalizing on this conclusion, it can be said that the relative decrease in trade between the CU countries is a probable consequence of Russia's accession to the WTO, since it would be more difficult for them to develop their exports, and a preemptive growth of trade between the CU members and third countries, among which we should particularly distinguish the EU countries.

Taking into account the revealed CU potential for creating trade in group 73, products from ferrous metals, the policy makers of these three countries should consider a situation favorable for the development of trade in this sector (or in the sector that unites groups 72 and 73) provided that the measures taken would not contradict the WTO rules.

At the same time, Russia's Treaty with the WTO envisages a decrease in the import tariff on products of group 73 from $14.5 \%$ to $7.1 \%$. As a consequence, the liberalization of the Common Customs Tariff of the Customs Union may ultimately escalate competition on the part of the European Union and China and may make allowances for trade flows for this group of products.

In order to develop trade within the Customs Union, it is necessary to promote the leveling of government support in the member countries by sectors, as well as of other macroeconomic parameters like credit conditions, taxation; the creation of a favorable climate for the inflow of direct foreign investments, primarily, to processing sectors; the gradual transition from the export of raw materials to the export of processed goods; the acceleration of accession to the WTO of Belarus and Kazakhstan, which are already operating under the Russian commitments to the WTO as far as the protection of their national markets is concerned but which still lack access to WTO advantages.

It will be very interesting to see in the future how the CU will develop, how its trade pattern will change, and what will cause this change; one such cause will, most probably, 
be the WTO.

Received 18 October 2013, Revised 7 October 2014, Accepted 20 April 2015

\section{References}

Anne Krueger, "Trade Creation and Trade Diversion Under NAFTA," NBER Working Paper 7429 (1999).

Constantine Michalopoulos and David Tarr, Are Customs Unions Economically Sensible in the Commonwealth of Independent States (Washington: World Bank 2004).

David Greenaway and Chris Milner, "Regionalism and Gravity," The University of Nottingham Research Paper 20 (2002).

Jacob Viner, The Customs Union Issue (New York and London: Carnegie Endowment for International Peace and Stevens \& Sons, 1950).

Jeffrey A. Frankel, editor, The Regionalization of the World Economy (Chicago: University of Chicago Press, 1998).

Luca De Benedictis and Roberta De Santis and Claudio Vicarelli, "Hub-and-Spoke or Else? Free Trade Agreements in the Enlarged EU A Gravity Model Estimate," European Network of Economic Policy Research Institutes Working Paper 37 (2005).

Lucio Vinhas De Souza, "An Initial Estimation of the Economic Effects of the Creation of the EurAsEC Customs Union on Its Members, " The World Bank Economic Premise 47 (2011).

Murray C. Kemp and Henry Y. Wan, “An Elementary Proposition Concerning the Formation of Customs Union.” Journal of International Economics 6 (1976).

Pravin Krishna, "Preferential Trade Agreements and the World Trade System." NBER Working Paper 17840 (2012). 